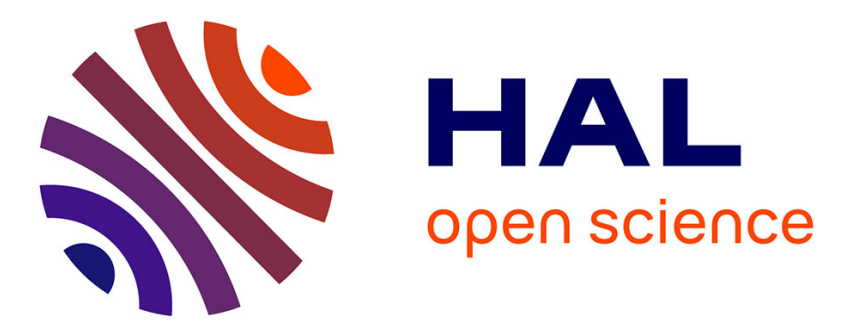

\title{
Use of Pulsed Nmr Spectroscopy to Measure the Amount of Solid Deposits As a Function of Temperature in Waxy Crudes
}

\author{
V. Ruffier-Meray, J. C. Roussel, A. D. Defontaines
}

\section{- To cite this version:}

V. Ruffier-Meray, J. C. Roussel, A. D. Defontaines. Use of Pulsed Nmr Spectroscopy to Measure the Amount of Solid Deposits As a Function of Temperature in Waxy Crudes. Revue de l'Institut Français du Pétrole, 1998, 53 (4), pp.531-535. 10.2516/ogst:1998048 . hal-02079016

\section{HAL Id: hal-02079016 \\ https://hal-ifp.archives-ouvertes.fr/hal-02079016}

Submitted on 25 Mar 2019

HAL is a multi-disciplinary open access archive for the deposit and dissemination of scientific research documents, whether they are published or not. The documents may come from teaching and research institutions in France or abroad, or from public or private research centers.
L'archive ouverte pluridisciplinaire HAL, est destinée au dépôt et à la diffusion de documents scientifiques de niveau recherche, publiés ou non, émanant des établissements d'enseignement et de recherche français ou étrangers, des laboratoires publics ou privés.

\section{(c)(1)}

Distributed under a Creative Commons Attribution| 4.0 International License 


\title{
USE O F PULSED N M R SPEC TRO SC O PY TO MEASURE THE AMOUNTOF SO LID IN W AXY CRUDES
}

\author{
V. RUFFIER-MERAY, J.-C. RO USSEL, A.-D. DÉFO NTAIN ES \\ Institut français du pétrole ${ }^{1}$
}

\section{UTILISATION DE LA SPECTROSCOPIE RMN PULSÉE POUR MESURER LA QUANTITÉ DE DÉPÔTS SOLIDES EN FONCTION DE LA TEMPÉRATURE DANS LES BRUTS PARAFFINIQUES}

La cristallisation des paraffines dans les pétroles bruts et même dans les gaz à condensat est un problème majeur dans le domaine de l'exploitation pétrolière. Afin d'évaluer ce risque, on utilise des modèles thermodynamiques. Ils permettent de calculer la température de cristallisation commençante (TCC) ou Wax Appearance Temperature (WAT) ainsi que la fraction cristallisée en fonction de la température (pour des températures inférieures à la TCC). Lors de leur développement, ces modèles doivent être évalués sur des données expérimentales. II existe dans la littérature et chez les pétroliers différentes méthodes pour mesurer la TCC, malheureusement il n'en est pas de même pour la fraction cristallisée en fonction de la température. Dans cet article, nous avons développé une méthode de RMN basse résolution afin de mesurer la fraction cristallisée en fonction de la température. Elle a d'abord été évaluée sur des mélanges de corps purs puis elle a été appliquée à des pétroles bruts. Les résultats ont été comparés à ceux obtenus par analyse calorimétrique différentielle ainsi qu'aux résultats du modèle.

\section{USE OF PULSED NMR SPECTROSCOPY TO MEASURE THE AMOUNT OF SOLID DEPOSITS AS A FUNCTION OF TEMPERATURE IN WAXY CRUDES}

Paraffin crystallization in crude oils and in gas condensates is a major problem for petroleum exploitation. Thermodynamic models are used to evaluate the risk. With them, one calculates the Wax Appearance Temperature (WAT) as well as the crystallized fraction as a function of temperature, for temperatures below the WAT. During development, these models are tested against experimental data. Although different methods for measuring the WAT are available in the literature and at petroleum companies, such methods unfortunately do not exist for measuring the crystallized fraction as

(1) 1 et 4 , avenue de Bois-Préau, 92852 Rueil-Malmaison Cedex - France a function of temperature. In this work, we have developed a low resolution NMR method for measuring the crystallized fraction as a function of temperature. The method was first evaluated using pure samples and was then applied to crude oils. The results were compared to those obtained both from differential calorimetry and from the model.

\section{UTILIZACIÓN DE LA ESPECTROSCOPIA RMN PULSADA PARA LA MEDICIÓN DE LA CANTIDAD DE SEDIMENTOS SÓLIDOS CON RESPECTO A LA TEMPERATURA EN LOS CRUDOS PARAFÍNICOS}

La cristalización de las parafinas en los petróleos crudos, e incluso en los gases de condensados, constituye un problema agudo en el aspecto de la explotación del petróleo. Con objeto de evaluar este riesgo, se utilizan modelos termodinámicos que permiten calcular la temperatura de cristalización inicial (TCl) o Wax Appearance Temperature (WAT), así como la fracción cristalizada en función de la temperatura (para temperaturas inferiores a la $\mathrm{TCl}$ ). Al proceder a su desarrollo, estos modelos se habrán de evaluar acorde a datos experimentales. En la literatura técnica profesional y también por parte de las empresas petroleras existen diversos métodos para la medición de la TCl, pero, desdichadamente, no ocurre lo mismo al tratarse de la fracción cristalizada, en función de la temperatura. Al proceder a este trabajo, hemos desarrollado un método de RMN de baja resolución con objeto de medir la fracción cristalizada en función de la temperatura. En primer lugar, se ha procedido a su evaluación mediante mezclas de cuerpos puros y, acto seguido, se ha aplicado a los petróleos crudos. Se ha procedido a continuación a la comparación de los resultados con aquellos obtenidos por análisis colorimétrico diferencial, así como a los resultados del modelo.

\section{INTRODUCTION}

Wax deposition is a major operating problem during production of oil and condensate in cold environment. Heavy components and more precisely heavy normal alkanes, with high melting temperatures, precipitate in 
pipelines or storage facilities. A better understanding of the crystallization process and the capacity to model the wax formation would help to overcome this problem. Thermodynamic models have been developed in order to calculate the Wax Appearance Temperature (WAT) and the amount of solid fraction versus temperature. In order to evaluate the model capabilities to calculate these properties, experimental data are necessary. Several methods exist to determine the WAT of the sample but very few are available to measure the amount of solid versus temperature. The work presented here is focused on the assessment of the Pulsed NMR spectroscopy method to measure the amount of solid versus temperature. The method has been developed, and the experimental procedures were set out together with the operating parameters. It has been used to measure amount of solid versus temperature on pure component mixtures and on crude oils. Results have been compared with those obtained by the Differential Scanning Calorimetry method and by modeling.

\section{NMR SPECTROSCOPY}

Measurements were performed with a Bruker Minispec PC 20 pulsed NMR spectrometer, operating at $20 \mathrm{MHz}$. In this method we used the fact that the relaxation speeds of protons belonging to a solid phase or a liquid one are different.

It can be seen on Figure 1 that solid protons have completely relaxed at $70 \mu \mathrm{s}$ and that, in contrast, relaxation of liquid protons can be neglected in this delay and even upto $300 \mu \mathrm{s}$ as plotted on the figure. Knowing that the amplitude of NMR signal is proportional to the number of protons, it is possible to evaluate the number of protons belonging either to the liquid phase or to the solid one, as explained in the following (Fig. 2). Signal amplitude at $t=0$ is proportional to the total number of protons in the sample. Extrapolation of the second part of the curve (i.e. between 40 and $100 \mu$ s) at $t=0$ is representative of the number of protons in the liquid phase. This extrapolation avoids calibration sequences which were presented by Pedersen (1991). Nevertheless, it (the extrapolation) has to deal with the $11 \mu \mathrm{s}$ "dead time" of the spectrometer, which prevents to sample the signal before this delay. Another issue was the sampling rate, which has to be as fast as possible to have a sufficient number of points on the curve. We could achieve a sampling rate of $2 \mu$ s. So it was possible to have 44 signal values between 11 and $100 \mu$ s. In this way, the amount of protons in the solid phase can be calculated with the Equation (1):

$$
\frac{\mathrm{H}_{\text {solid }}}{\mathrm{H}_{\text {total }}}=\frac{S_{t=0}^{S+L}-S_{t=0}^{L}}{\left(S_{t=0}^{S+L}-S_{t=0}^{L}\right)+S_{t=0}^{L}}
$$

where $\mathrm{H}_{\text {solid }}$ is the number of protons in the solid phase, $\mathrm{H}_{\text {total }}$ is the total number of protons in the mixture, $S^{S+L}$ is the amplitude of the signal for the sample containing a solid $(S)$ and a liquid $(L)$ phases and $S^{L}$ is the amplitude of the signal for the sole liquid phase of the sample, extrapolated at $t=0$.

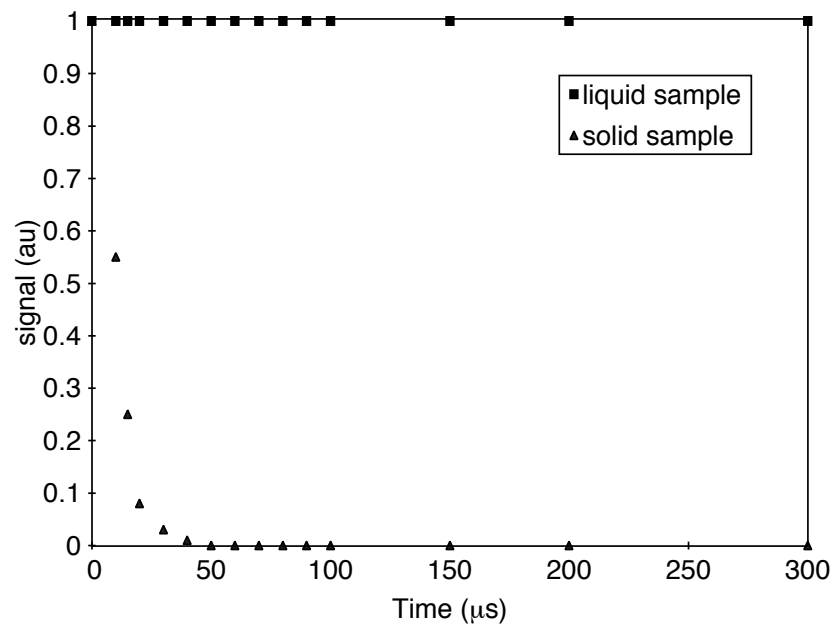

Figure 1

Relaxation of protons in a liquid and in a solid sample.

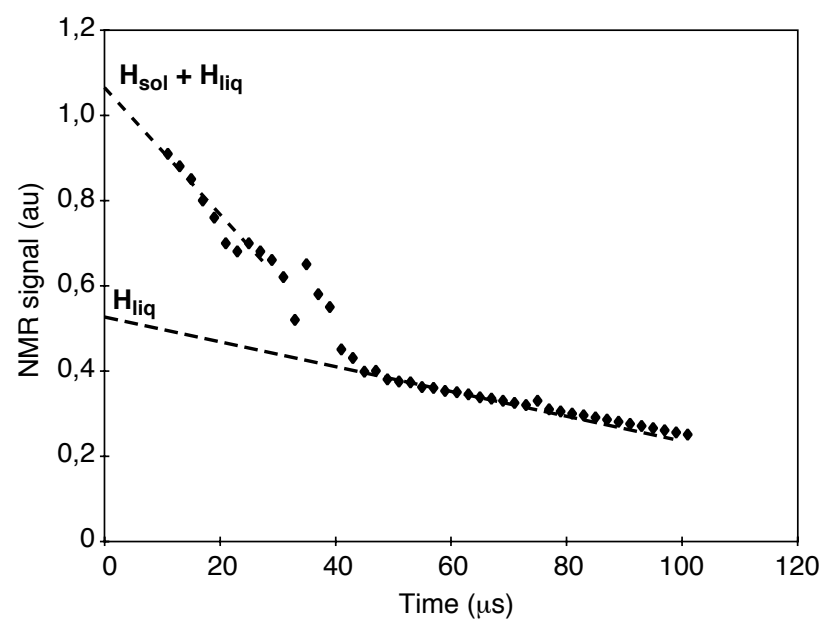

Figure 2

Relaxation curve of a mixture of liquid and solid phases. 


\subsection{Experimental parameters}

The relaxation delay was $2 \mathrm{~s}$ after a $90^{\circ}$ pulse width of $2 \mu \mathrm{s}$. The signal was measured between $11 \mu \mathrm{s}$ ("dead time" of the spectrometer) and $100 \mu$ s at $2 \mu$ s time interval. The same acquisition was repeated 100 times. Samples were contained in a capillary tube, the volume of which was $1 \mathrm{~cm}^{3}$. It has been checked that all the volume of the sample was irradiated. In this condition, the NMR signal is proportional to the amount of protons.

\section{MEASUREMENTS ON PURE COMPONENT MIXTURES}

In order to evaluate the sensibility of the method, we performed some experiments with pure component mixtures. We prepared various mixtures of hexatriacontane in $n$-heptane and for each of these mixtures we measured the amount of protons in the solid phase. The spectrometer was regulated at $40^{\circ} \mathrm{C}$. At this temperature, hexatriacontane is considered insoluble in $n$-heptane. Results obtained are presented on Figure 3. Concentrations of hexatriacontane in mixtures varied between 6 and $48 \%$ in weight. The difference between weighted and measured concentrations of hexatriacontane was about $5 \%$. In order to evaluate the accuracy of the method two mixtures with the same concentration were prepared and concentration of protons in the solid phase were measured. The difference between the two determinations was $5 \%$. We considered that this value was representative of the accuracy of the method.

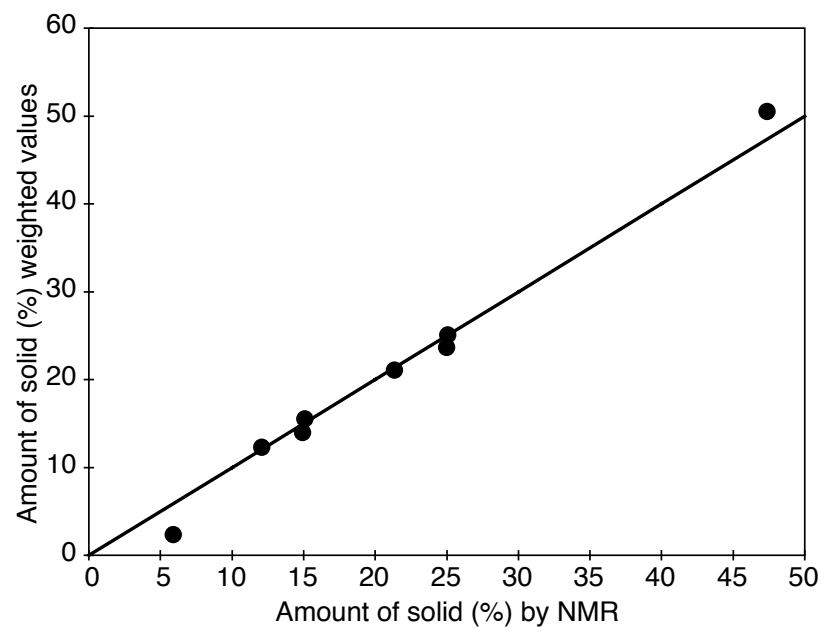

Figure 3

Comparison between the measured and the weighed amount of solid (hexatriacontane in heptane).

\section{MEASUREMENTS ON CRUDE OILS}

The purpose of this study was to measure the amount of solid fraction versus temperature in crude oils. So the probehead of the spectrometer was regulated at various temperatures (between 40 and $0^{\circ} \mathrm{C}$ ) and for every temperature the NMR spectrum was measured in the same experimental conditions as for the pure component mixtures. Three crude oils were studied. For one of them results were compared to those obtained with DSC and those of the thermodynamic model CRYSPAR (Calange, 1996).

\subsection{Determination of the amount of solid knowing the number of proton in the liquid and solid phases}

As we saw it here above, for pure component mixtures calculation of the amount of solid knowing the number of protons is simple because and the compositions of the liquid and solid phases are easily available. Considering crude oils it is more difficult because compositions of the liquid and solid phases are not available and moreover are different at each temperature. For this purpose, crude oils had to be analysed in order to evaluate the number of proton in the solid and in the liquid phases. Analyses are described hereafter.

In a first time, the crude oil was split by distillation into two fractions, i.e.: a light fraction $\mathrm{C}_{200}$ and a heavy fraction $\mathrm{C}_{200+}$. After that, the heavy fraction was split by crystallisation in methyl ethyl ketone at low temperature $\left(-20^{\circ} \mathrm{C}\right)$ into two fractions: the dewaxed $\mathrm{C}_{200+}$ and the "wax" fraction. Then the dewaxed $\mathrm{C}_{200+}$ and the $\mathrm{C}_{200-}$ were recombined in order to obtain the "matrix". On each fraction (matrix and wax), elemental analysis was performed in order to measure the ratio between the number of carbon and of hydrogen atoms. Then the amount of solid can be calculated using Equation (2):

$$
\% \mathrm{H}_{\text {solid }}=\frac{\left(S_{t=0}^{S+L}-S_{t=0}^{L}\right) \frac{M M_{\text {solid }}}{n b \cdot \mathrm{H}_{\text {solid }}}}{\left(S_{t=0}^{S+L}-S_{t=0}^{L}\right) \frac{M M_{\text {solid }}}{n b \cdot \mathrm{H}_{\text {solid }}}+S_{t=0}^{L} \frac{M M_{\text {liquid }}}{n b \cdot \mathrm{H}_{\text {liquid }}}}
$$

where $M M$ are the molecular weights of the solid phase or the liquid one and $n b \cdot \mathrm{H}$ are the numbers of hydrogen atoms per molecule in the solid or in the liquid phases.

In order to determine the ratio $\frac{M M}{n b \cdot \mathrm{H}}$ assumptions were made, as given in the following. A representative molecule for each phase (liquid and solid) can be expressed as: $n\left(\mathrm{C}_{b} \mathrm{H}\right)$, where $b$ is the ratio between the numbers of carbon (C) atoms and hydrogen $(\mathrm{H})$ atoms. It can be calculated 
using the elemental analysis results (Eq. 3). The ratio $\frac{M M}{n b \cdot \mathrm{H}}$ is then obtained with Equation (4):

$$
\begin{aligned}
b & =\frac{\% \mathrm{C} / 12}{\% \mathrm{H}} \\
\frac{M M}{n b \cdot \mathrm{H}} & =\frac{\% \mathrm{C}}{\% \mathrm{H}}+1
\end{aligned}
$$

Near the WAT, the composition of the liquid phase was considered to be the same as the crude oil one and the composition of the solid phase was considered to be the same as the "wax" one. At low temperature, the liquid phase was represented by the "matrix" and the solid phase by the "wax".

\subsection{Results}

Results obtained are presented on Figures 4 and 5. It can be seen on Figure 4 that the three crude oils do not show the same behaviour. For the first crude oil (crude oil $V$ ) the amount of solid is quite low, even at low temperature. On the contrary, the crude oil $D$ shows a high amount of solid between 0 and $30^{\circ} \mathrm{C}$. It appears that amount of solid below $1 \%$ could not be measured and so the WAT (amount $=0$ ) was not detected. The NMR spectroscopy is not sensitive enough to evaluate the WAT. It is in agreement with results on pure component mixtures, where the concentration of solid fraction has to be above $5 \%$ to be properly measured.

On Figure 5 NMR results are compared to DSC and modeling one. There is a good agreement between the two experimental techniques and the modeling. Discrepancies are acceptable knowing the accuracy of each method.

Field data were not available to compare with our results. However considering Figure 4 it appears that it will be more difficult to produce the crude oil $D$ than the crude oil $V$. These qualitative evaluation is in agreement with observations made by the companies who are in charge of the exploitation of these crude oils.

\section{CONCLUSION}

It has been possible to measure the amount of solid versus temperature for three crude oils, using pulsed NMR technique. An experimental procedure was developed in order to evaluate the NMR value of the signal at $t=0$ for the liquid and for the solid phases. The method has been evaluated with pure component mixtures. It has been shown that it was possible to measure the amount of solid with an accuracy of about $5 \%$.

Three measurement have been done with crude oils. In order to transform the NMR signal (which represent a ratio in term of number of hydrogen atoms) in a ratio (in weight)

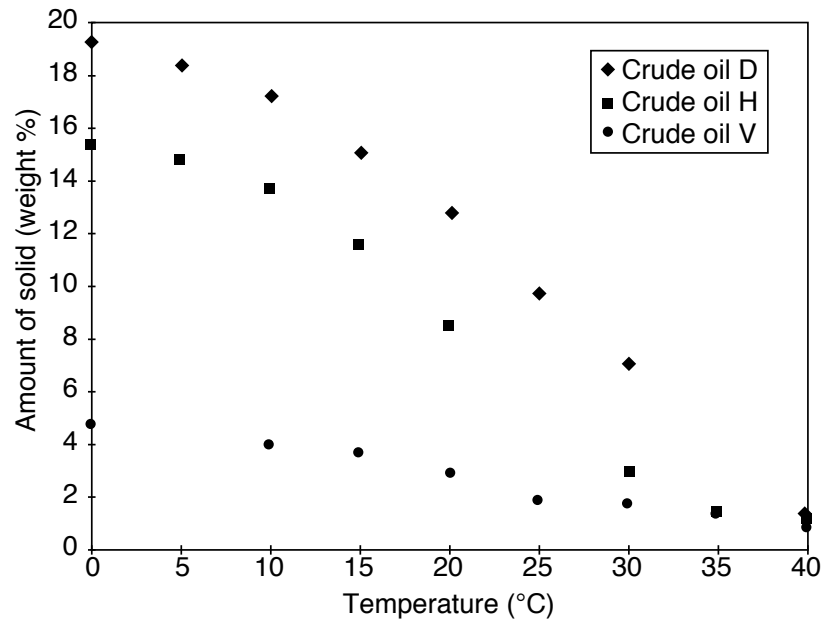

Figure 4

Amount of solid measured by NMR for three crude oils

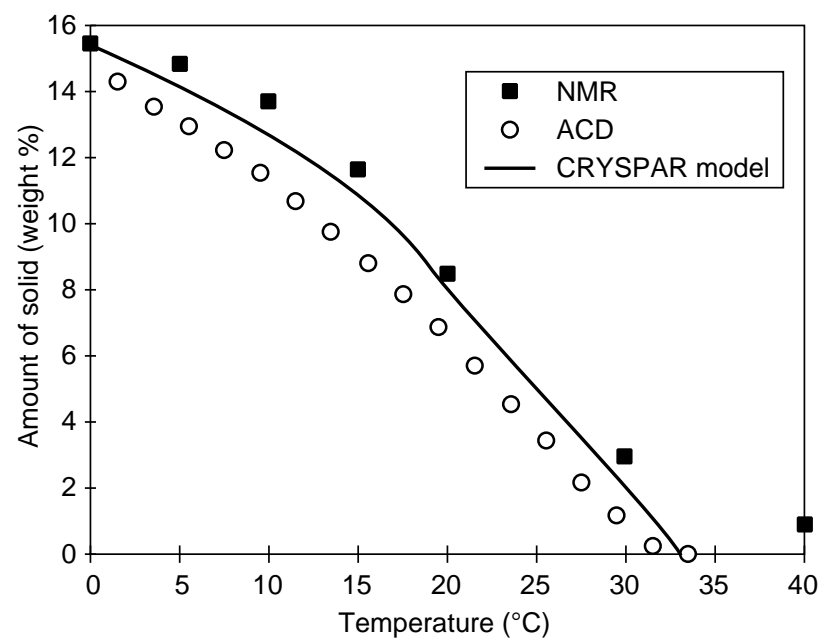

Figure 5

Comparison between NMR, ACD and thermodynamic modeling results for crude $\mathrm{H}$. 
between the amount of solid and liquid phases assumptions were made to estimate the composition of solid and liquid phases at the different temperatures. Results have been compared to the DSC one and a good agreement was obtained. Unfortunately field data were not available forcomparison but the qualitative information is correct regarding the difficulty of exploitation.

The technique could be improved with higher sampling rate of the signal and using the mathematical treatment of the signal as proposed by Le Botlan (1997). For a more reliable interpretation of the results, a precise knowledge of the composition of liquid and solid phases of the tested sample would be required.

Nevertheless, the NMR method is a powerful technique to obtain the amount of solid versus temperature in crude oils. Data can be used to fit or validate thermodynamic model calculations. The later are then used to predict the amount of solid at various conditions (temperature and pressure) of exploitation.

\section{ACKNOWLEDGMENT}

Part of this work was carried out in partnership with Elf and Total. The authors express their thanks to Elf and Total to authorize them to publish this work.

\section{REFERENCES}

Calange S. (1996) Modélisation thermodynamique compositionnelle de la cristallisation des bruts paraffiniques. Thesis, University of Pau and Pays de l'Adour.

Le Botlan D.J and Ouguerram L. (1997) Spin-spin relaxation time determination of intermediate states in heterogeneous products from free induction decay NMR signals. Analytical Chimica Acta, 34, 339-347.

Pedersen W.B., Hansen A.B., Larsen E. and Nielsen A.B. (1991) Wax precipitation from North Sea crude oils. 2. Solid-phase content as function of temperature determined by pulsed NMR. Energy and Fuels, 5, 908-913.

Final manuscript received in May 1998 